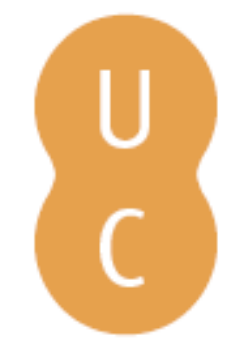

\title{
pompalina
}

\section{Nutrient dynamics in the intertidal pools of the Mondego estuary: III - the importance of nutrient effluxes to macroalgal growth (Enteromorpho sp.)}

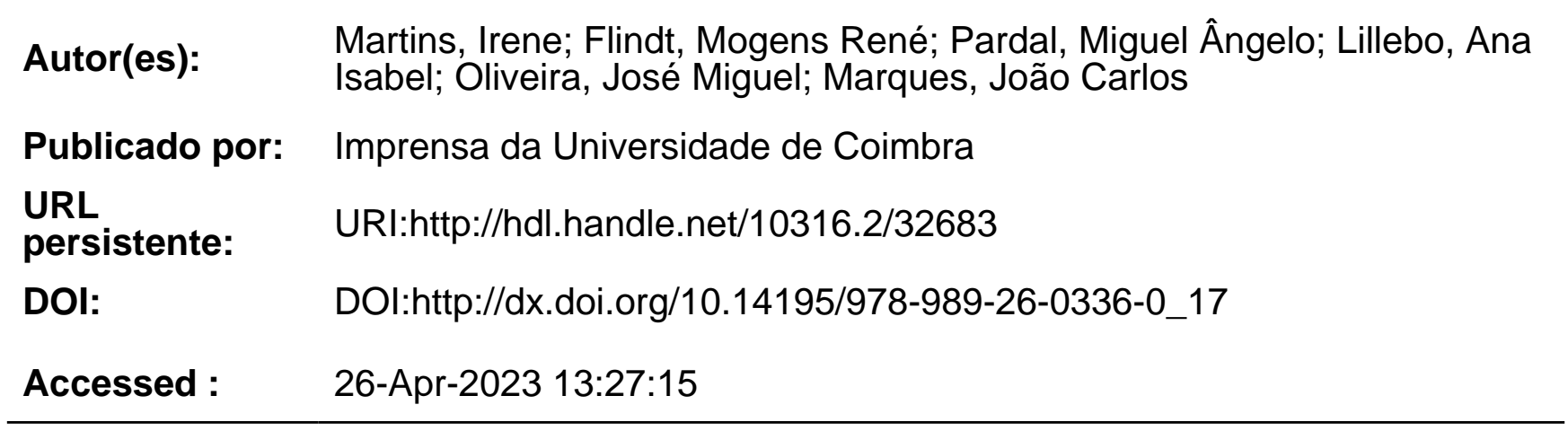

A navegação consulta e descarregamento dos títulos inseridos nas Bibliotecas Digitais UC Digitalis, UC Pombalina e UC Impactum, pressupõem a aceitação plena e sem reservas dos Termos e Condições de Uso destas Bibliotecas Digitais, disponíveis em https://digitalis.uc.pt/pt-pt/termos.

Conforme exposto nos referidos Termos e Condições de Uso, o descarregamento de títulos de acesso restrito requer uma licença válida de autorização devendo o utilizador aceder ao(s) documento(s) a partir de um endereço de IP da instituição detentora da supramencionada licença.

Ao utilizador é apenas permitido o descarregamento para uso pessoal, pelo que o emprego do(s) título(s) descarregado(s) para outro fim, designadamente comercial, carece de autorização do respetivo autor ou editor da obra.

Na medida em que todas as obras da UC Digitalis se encontram protegidas pelo Código do Direito de Autor e Direitos Conexos e demais legislação aplicável, toda a cópia, parcial ou total, deste documento, nos casos em que é legalmente admitida, deverá conter ou fazer-se acompanhar por este aviso.

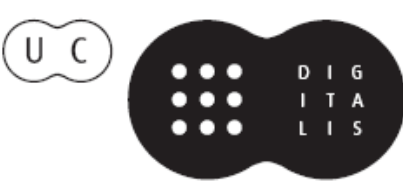


MIGUEL ÂNGELO PARDAL JOÄO CARLOS MARQUES MANUEL AUGUSTO GRAÇA Scientific Editors

\section{Aquatic Ecology of the Mondego River Basin Global Importance of Local Experience}




\author{
MIGUEL ÂNGELO PARDAL \\ JOẢO CARLOS MARQUES \\ MANUEL AUGUSTO GRAÇA \\ Scientific Editors
}

\title{
Aquatic Ecology of the Mondego River Basin Global Importance of Local Experience
}




COORDENAÇÃO EDITORIAL
Imprensa da Universidade de Coimbra
CONCEPÇÃO GRAFICA
António Barros
INFOGRAFIA
António Resende
Estimulus [design] • Coimbra
EXECUÇÃO GRAFICA
GRAFIASA
ILUSTRAÇÃO DA CAPA
P. P. Cunha e ]. Dinis
ISBN
972-8704-04-6
DEPOSITO LEGAL
I75038/02

(C) JANEIRO 2002, IMPRENSA DA UnIVERSIDADE DE COIMBRA

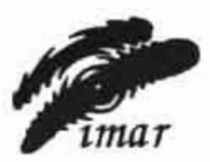

CPIMAR

imar

OBRA PUBLICADA COM O PATROCINIO DE:

IMAR - INSTITUTO DO MAR

IPIMAR - INSTITUTO DE INVESTIGAÇĀO DAS PESCAS E DO MAR 

Irene Martins '

MOgens RENÉ FUINDT ${ }^{2}$

Miguel Ângelo PARdal '

ANA ISABEl LILLEBø'

José Miguel Oliveira 1

Joảo Carlos Marques '

\title{
NUTRIENT DYNAMICS INTHE INTERTIDAL POOLS OFTHE MONDEGO ESTUARY. \\ III - THE IMPORTANCE OF NUTRIENT EFFLUXES TO MACROALGAL GROWTH (Enteromorpha sp.)
}

\begin{abstract}
The aim of the present work was to evaluate the importance of nutrient fluxes across the sediment-water interface to the growth of opportunistic macroalgae (Enteromorpha sp.) within tidal pools of an intertidal estuary. We hypothesised that different tidal pools, in relation with onganic matter content in the sediment and the presence/absence of rooted-macrophytes, promote distinct growth responses of Enteromorpho sp. Nutrient dynamics ( $\mathrm{PO}_{4}-\mathrm{P}, \mathrm{NH}_{4}-\mathrm{N}$ and $\mathrm{NO}_{1}-\mathrm{N}$ ) and Enteromorpho intestinalis growth were assessed during low-tide period in 4 different places: a sandy bare bottom pool, muddy pools (a bare bottom pool and a Sportina maritima covered pool) and the low-depth subtidal channel. Macroalgal growth in the subtidal area was estimated to compare with results from the tidal pools. Results showed that the growth rate of $E$ intestinalis was higher in the muddy bare bottom pool and statistically different from growth in the other places. No significant differences were found between macroalgal growth in the S. maritima covered pool, the sandy pool and the channel. The differences are partially explained by different nutrient dynamics between the muddy bare bottom pool and the other places. The availability of $\mathrm{NH}_{4}-\mathrm{N}$ was higher in the muddy bare bottom pool, followed by the S. maritima covered pool, the channel and the sandy bare bottom pool. N:P atomic ratios of the water suggested that, with the exception of the muddy bare bottom pool, all the other places showed a potential $\mathrm{N}$-limitation for primary production. Results also suggested that Spartina maritima affect the nutrient dynamics in tidal pools. However in this type of pools, the growth of $E$. intestinalis may also be affected by shading caused by the rootedmacrophyte presence. In the channel, other factors (e.g. hydrodynamics) affect macroalgal growth, which determines differences in relation with tidal pools. At the system level, these results suggest that in terms of nutrient availability, the occurrence of macroalgal blooms may be independent from external inputs.
\end{abstract}

i' IMAR Instituto do Mar, Centro Interdisciplinar de Coimbra a/c Departamento de Zoologia, Universidade de Coimbra, 3004-517 Combra, Portugal

Diological Institute, SDU. University of Odense, Campusvej 55, DK.-5230 Odense M. Denmark 


\section{Introduction}

Algal abundance in coastal eutrophic systems is largely related with physical factors such as exposure to wind, waves, water exchange (Morand and Briand 1996. Pihl et al. 1999) and topography (Hernández et al. 1997). However in intertidal shallow estuaries, where the coupling between benthic and pelagic processes is very significant (in Falcão and Vale 1990, Flindt et al. 1999), macroalgal growth may at a certain extent be determined by the exchange of nutrients across the sediment-water interface. For example, in Narragansett Bay (USA), regeneration from the sediments can provide enough phosphate to support $50 \%$ of the primary production in the water column (in Valiela 1995), while in the archipelago of southern Fyn (Denmark), during spring (June), $20 \%$ of inorganic nitrogen comes from the sediment (in Morand and Briand, 1996). In the same way, in the Venice Lagoon, the water-sediment nutrient fluxes were considered as a major factor controlling algal growth (Sfriso 1995).

The south arm of the Mondego estuary is a shallow intertidal system characterised by an extensive tidal pool formation during low-tide (Flindt et al. 2002). Intertidal pools differ in relation with organic matter content in the sediment, rootedmacrophytes presence and mean residence time of nutrients (Flindt et al. 2002). These characteristics may determine different nutrient availability in different intertidal pools (Flindt et al. 2002. Lillebø et al. 2002a). Throughout the last decade, opportunistic green macroalgae mostly Enteromorpha spp., were the dominant primary producers in the south arm of the Mondego estuary (Pardal 1998, Martins 2000, Pardal et al. 2000, Martins et al. 200I) and $E$ intestinalis (L) Link and $E$ compressa (L) Greville constituted the most abundant species (Martins 2000, Martins et al. 2001). During the spring of 1993, the biomass of green macroalgae reached a maximum value of $500 \mathrm{~g}$ AFDW. $\mathrm{m}^{2}$ (Pardal et al. 2000). On a yearly basis, at the beginning of the growing season (late winterlearly spring), new individuals of Enteromorpha proliferate in the muddy areas, while later in spring, larger macroalgal accumulations tend to occur in the inner sandy areas of the south arm of the estuary.

The aim of this work was to assess for the contribution of nutrient fluxes between sediment and water-interface to macroalgal growth in different intertidal pools of the Mondego estuary. Besides verifying the importance of benthic-pelagic interactions on ongoing processes in shallow intertidal systems, the present work may also contribute to understand the annual pattern of macroalgal coverage in the Mondego estuary.

\section{Material and methods}

\section{Experimental procedure}

The work was carried out on the 17 $7^{\text {th }}$ of July 1999 from 9 am until $5 \mathrm{pm}$ (low-tide period) in the south arm of the Mondego estuary (Fig. I). Three different experimental places located in the intertidal area were chosen in relation to sediment composition 
and the presence or absence of rooted-macrophytes (for a better characterisation see Flindt et al. 200I): a organic-poor sandy pool (0.95\%), a organic-rich unvegetated muddy pool (5\%) and a organic-rich Spartina maritima pool (8\%). For comparison with the tidal pools, a fourth experimental place located in the subtidal channel (average depth during low-tide $0.5-1 \mathrm{~m}$ ) was chosen to assess for macroalgal growth in the subtidal areas where the nutrient dynamics is not so dependent on the sediment-water interface.

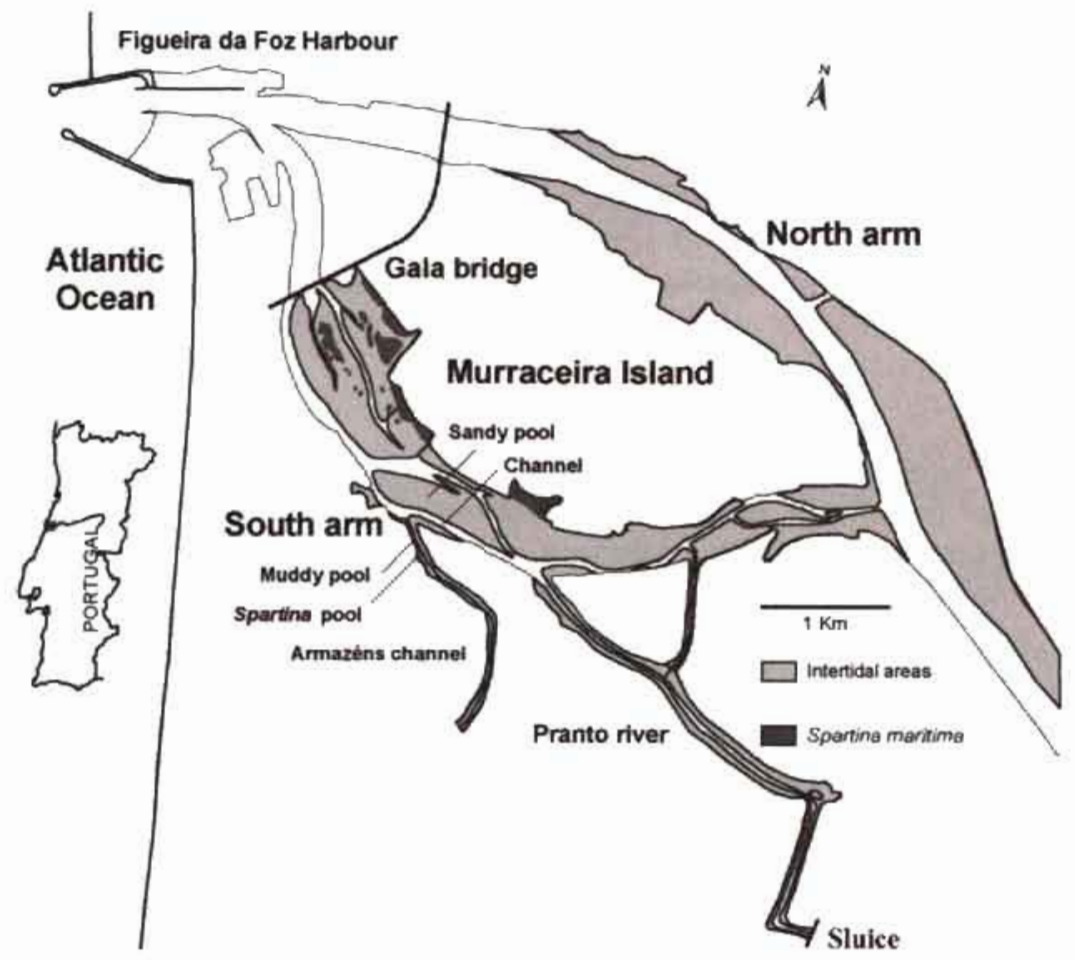

Figure I. The Mondego estuary with location of the field stations (Picture by R. Lopes)

At that time of the year, Enteromorpho was not very abundant in the south arm of the estuary (personal observation) nevertheless, healthy individuals of Enteromorpho intestinalis were harvested and taken to the experimental areas inside cages containing estuarine water locally collected. All E intestinalis individuals were cut to the same initial length (approximately) (Table 1) and they were placed inside the tidal pools in such a way that they could not shade themselves. For growth estimation in the channel, Enteromorpha replicates were placed inside experimental plexiglass cages surrounded laterally and in the bottom by plastic net with a mesh size of 2-3 mm, which allowed water circulation inside. Experimental cages were always kept immersed by ropes fixed to sticks buried in the sediment (for a more detailed description see Martins 2000). 
Table I. Enteromorpho intestinalis individuals used in the experiment: number of replicates (N), initial length of replicates $(\mathrm{cm})$, exposure time of replicates (initial time-final time) and average specific growth rate $\left(\mathrm{h}^{-1}\right)$.

\begin{tabular}{ccccc}
\hline & Sandy pool & Channel & Muddy pool & Spartina pool \\
\hline $\mathrm{N}$ & 12 & 15 & 8 & 11 \\
\hline $\begin{array}{c}\text { Initial length } \\
(\mathrm{cm})\end{array}$ & 20 & 20 & 23 & 20 \\
\hline $\begin{array}{c}\text { Experimental } \\
\text { hours } \\
\text { (with } \\
\text { macroalgae) }\end{array}$ & $\begin{array}{c}11.40 \mathrm{am}- \\
4.10 \mathrm{pm}\end{array}$ & $\begin{array}{c}12.25 \mathrm{am}- \\
4.10 \mathrm{pm}\end{array}$ & $\begin{array}{c}12.45 \mathrm{am}- \\
5 \mathrm{pm}\end{array}$ & $\begin{array}{c}11.45 \mathrm{am}- \\
5.15 \mathrm{pm}\end{array}$ \\
\hline $\begin{array}{c}\text { Average growth } \\
\left(\mathrm{h}^{-1}\right)\end{array}$ & 0.0193 & 0.0212 & 0.0329 & 0.0214 \\
\hline
\end{tabular}

The initial and final length $(\mathrm{cm})$ of all macroalgal replicates was registered and macroalgal growth was estimated by a mathematical deduced formula considering some assumptions. Enteromorpho thallus is considered as a cylinder with a wall one cell in thickness and its growth is two-dimensional (in Poole and Raven 1997). In order to infer growth rate in weight from length variation, Enteromorpha is considered as a volume which, increases proportionally in length $(a)$ and width $(b)$. No thickness $(c)$ or density $(\gamma)$ variations were considered and it was assumed that macroalgal growth in weight increases exponential by the formula (e.g. Brown and Rothery 1994):

$$
W_{t}=W_{0} \times e^{k_{-} t}
$$

$W_{0}$ - initial weight, $W_{1}$ - final weight, $t$ - experimental time, $k_{w}$ - specific growth rate (time unit').

Density $(\gamma)$ is defined as:

$$
y=\frac{W}{V}
$$

\section{W-weight, V-volume}

Equation 2 may be written in function of the weight $(W)$, considering the volume of a cylinder ( $\left.V=\pi \times \frac{1}{2} a \times \frac{1}{2} b \times c\right)$ and the assumptions made above:

$$
W_{t}=y_{t} \times \pi \times \frac{1}{2} a_{t} \times \frac{1}{2} b_{t} \times c_{t}
$$


$\gamma_{t}$ - macroalgal density in time $\mathrm{t}$ (weight/volume) and the other factors are the volume of the thallus also at time ( $t)$. In the same way as $W_{4}$ an identical formula may be written for $W_{0}$.

Substituting in equation 1, we obtain:

$$
y_{1} \times \pi \times \frac{1}{2} a_{t} \times \frac{1}{2} b_{t} \times c_{t}=y_{0} \times \frac{1}{2} a_{0} \times \frac{1}{2} b_{0} \times c_{0} \times e^{k w . t}
$$

Assuming that

$$
a_{t}=a_{0} \times e^{k a t} \quad \text { and } \quad b_{t}=b_{0} \times e^{k b . t}
$$

and substituting in equation 4 , we obtain

$$
y_{t} \times \pi \times \frac{1}{2} a_{0} \times e^{k+t . t} \times \frac{1}{2} b_{0} \times e^{k b t t} \times c_{t}=y_{0} \times \frac{1}{2} a_{0} \times \frac{1}{2} b_{0} \times c_{0} \times e^{k w t}
$$

Considering, as previously mentioned, that $\gamma_{0}=\gamma_{t}, c_{0}=c_{t}, k_{a}=k_{b}=k$. equation 6 may be simplified to:

$$
2 k=k_{w}
$$

$k_{w}$ - growth rate based on weight variation and $k$ is the analogous rate for length variation.

From equation 7 it is possible to calculate macroalgal growth rate in weight from the growth rate in length (or width) variation.

In all experimental places, initial and final measurements of water temperature. salinity and dissolved oxygen were carried out and water samples ( $10 \mathrm{ml}$ volume) were taken hourly for posterior quantification of dissolved reactive phosphate ( $P O_{4}-\mathrm{P}$ ). ammonia $\left(\mathrm{NH}_{4}-\mathrm{N}\right)$ and nitrate $\left(\mathrm{NO}_{3}-\mathrm{N}\right)$. All water samples were filtered in the field through Whatman GF/F filters and stored in ice. In the laboratory, samples were kept at $-18^{\circ} \mathrm{C}$ until analysis in a rapid flow autoanalyser (RFA 300 Alpkem) (see also Flindt et al. 2002, Lillebø et al. 2002a). PFD was measured using a quantum sensor LICOR LI-1000.

Significant differences between macroalgal growth rates in different experimental places were assessed by one-single factor ANOVA with unequal $n$ (Sokal and Rolf 1995) after tests of normality (Kolmorogov's test) and homogenerty (Bartlett's test) had been carried out A multiple comparison test (Tukey's test) for unequal $n$ was performed to discriminate for differences between samples (Zar 1999).

\section{Results}

Temperature, salinity, dissolved oxygen variation and PFD

Over the experimental period and in all experimental places, temperature didn't show important variations. As expected, dissolved oxygen increased from morning to the middle of the day and from 4 p.m. on, it started to decrease again (Figs. $2 \mathrm{a}$ and b). 
The initial and final salinity measurements suggest that through the experimental period and in all places, salinity was high (ranging between 26 and 28) and showed no variations. Although it was summer, the weather was very cloudy and a maximal PFD of $400 \mu$ mol.ph.m ${ }^{2} \cdot 5^{-1}$ was registered.

A

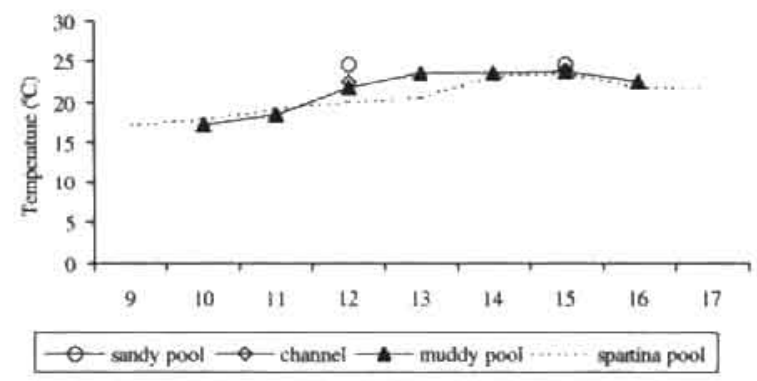

B

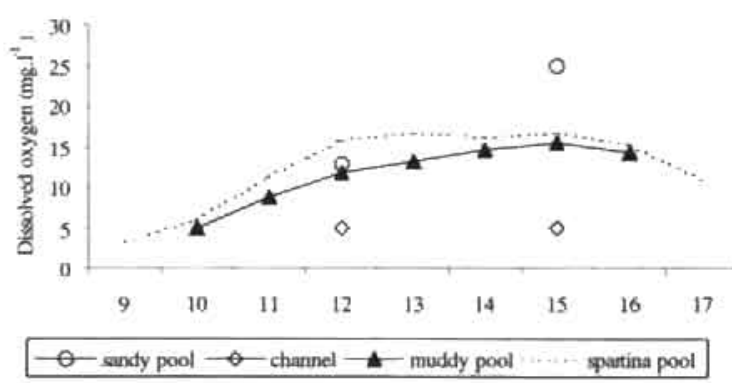

Figure 2 Variation of temperature $\left({ }^{\circ} \mathrm{C}\right)(\mathrm{A})$ and dissolved oxygen (mgl-1) (B) throughout experimental period in the different places. In the channel and in the sandy. pool, only initial and final measurements were done.

$\mathrm{PO}-\mathrm{P}, \mathrm{NH}_{4}-\mathrm{N}$ and $\mathrm{NO}_{3}-\mathrm{N}$ variation

In the Spartina maritima covered pool, $\mathrm{PO}_{4}-\mathrm{P}$ concentration showed an important increase from 9 to 10 am but then it was kept more or less constant. Furthermore, throughout the experimental period, S. maritima pool showed the highest PO4-P

278 concentrations. Also in the muddy bare bottom pool, $\mathrm{PO}+\mathrm{P}$ concentration didn't show important variations and the same tendency was observed in the sandy bare bottom pool, where $\mathrm{PO}_{4}-\mathrm{P}$ concentrations were similar to the ones of the muddy bare bottom pool (Fig. 3a)

Initially, both the pattern of $\mathrm{NH}_{4}-\mathrm{N}$ variation and the concentration values were very similar in the muddy bare bottom pool and in the Spartina maritima pool, but from 11 to 12 am this situation changed. While in the muddy bare bottom pool, $\mathrm{NH}_{4}-\mathrm{N}$ concentration kept increasing gradually until the end of the experiment, in the Spartino pool, from $1 /$ to $12 \mathrm{am}, \mathrm{NH}_{4}-\mathrm{N}$ decreased significantly and then it didn't show 
important variations. In the sandy pool, $\mathrm{NH}_{4}-\mathrm{N}$ concentration was very low comparatively to the other places and it decreased more significantly in the first experimental hour (Fig. 3b).

The concentration of $\mathrm{NO}_{3}-\mathrm{N}$ in the channel was considerably higher than in the other places and it didn't show important variations. In the Spartina pool, NOy-N concentration decreased exponentially from 9 to $1 \mathrm{lam}$ and then it decreased smoothly until the end of the experiment. In the muddy pool, $\mathrm{NO}_{2}-\mathrm{N}$ concentration also showed a significant decrease, although more gradual than in the Spartona pool. The sandy pool didn't show important variations, although the final value was lower than the initial one (Fig. 3c).

A

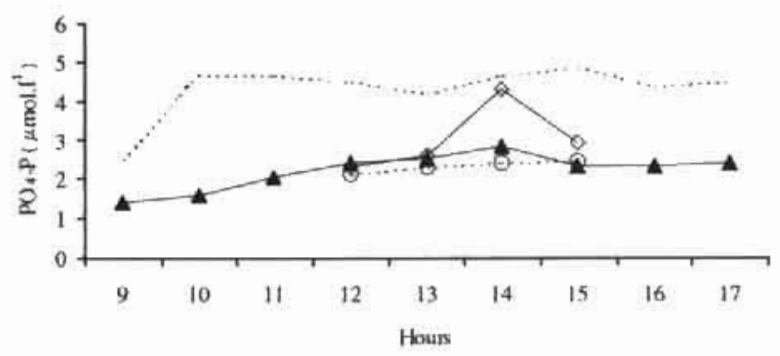

B

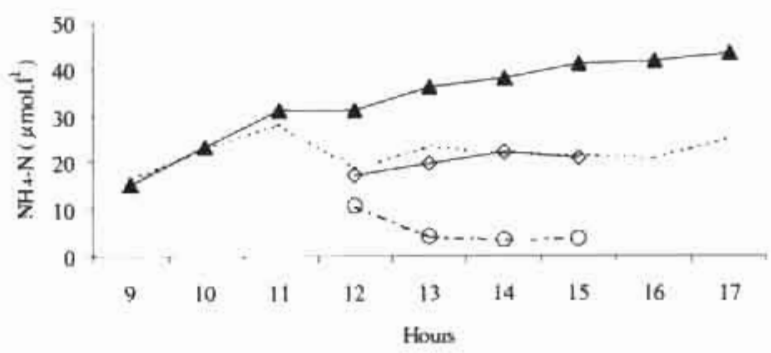

C

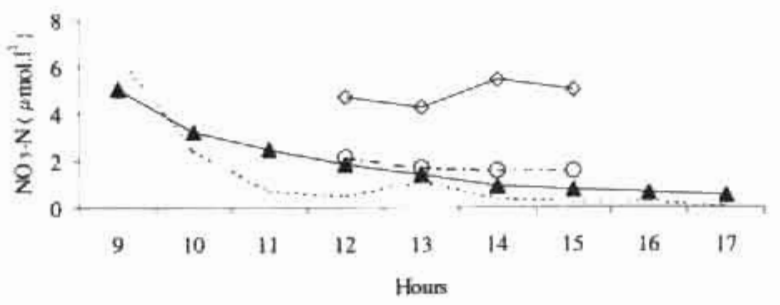

279

$-\theta$ - sandy pool $\rightarrow$ - channel $\rightarrow$ - muddy pool $\cdots$ spartina pool

Figure 3. Nutrient dynamics throughout the study period in experimental areas. A - PO+ $P$ variation, B $\mathrm{NH}+\mathrm{N}$ variation. $\mathrm{C}$ - NO. $\mathrm{N}$ variation. 
The muddy area showed higher N:P ratios of the water, close to the Redfield ratio. while the other places showed very low N:P ratios, especially, the sandy pool (Fig. 4).

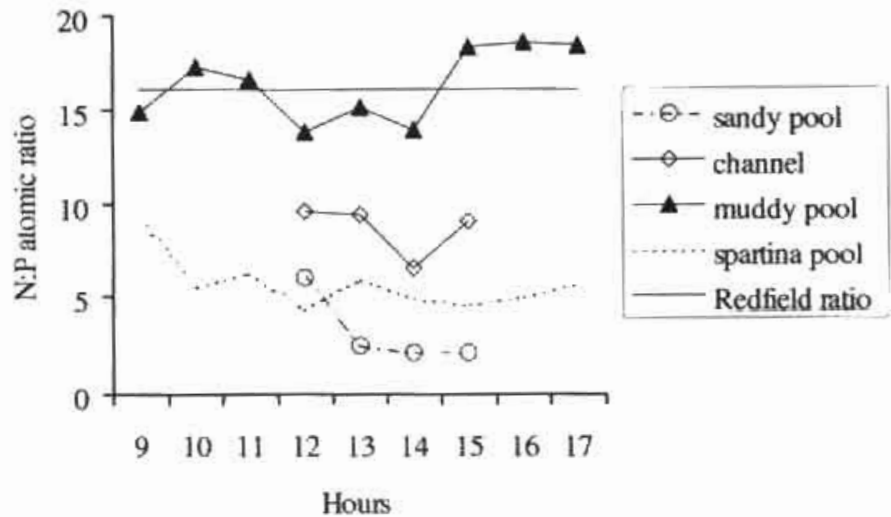

Figure 4. Variation of N:P atomic ratio of the water in all experimental places.

Macroalgal growth rate

The average Enteromorpha growth rate was higher in the muddy bare bottom pool $\left(0.0329 \mathrm{~h}^{-1}\right)$, followed by the subtidal channel $\left(0.0212 \mathrm{~h}^{-1}\right)$, the Spartina maritima covered pool $\left(0.0200 \mathrm{~h}^{\prime \prime}\right)$ and the sandy bare bottom pool $\left(0.0193 \mathrm{~h}^{\prime \prime}\right)$ (Fig. 5). These results corresponded to significant growth differences between experimental areas (ANOVA, $p<0.05$ ). Macroalgal growth in the muddy bare bottom pool was significantly different from growth in the other places (Tukey test, $p<0.05$ ) but $E$ intestinalis growth was not statistically different in the Spartina maritima covered pool. the sandy pool and the channel (Tukey test, $p>0.05$ ).

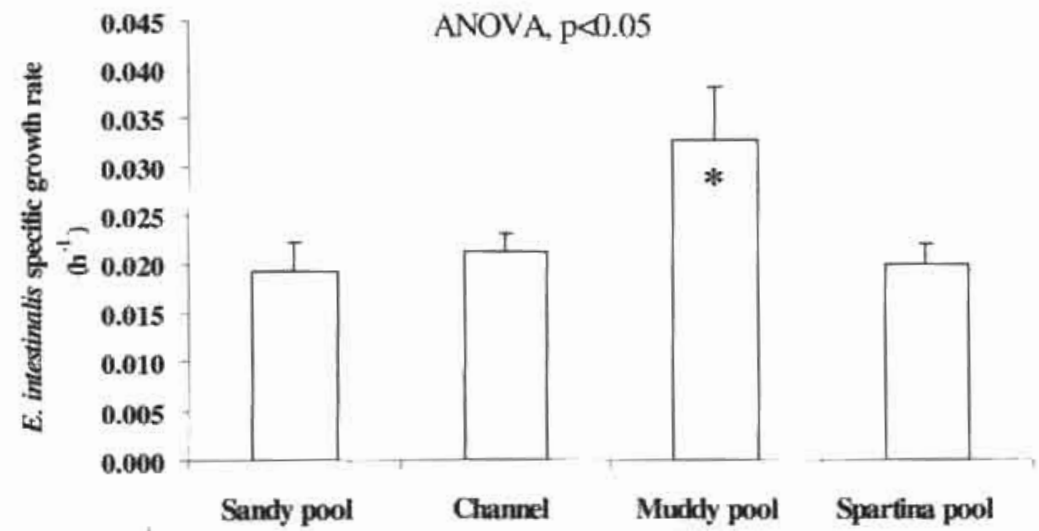

Figure S. Average Enteromorpho intestinalis specific growth rate + I standard error in experimental areas. Macroalgal growth was statistically different between experimental areas (ANOVA, $p<0.05$ ): Enteromorpha intestinalis growth rate in the muddy pool was significantly different from growth in the other places (Tukey test, $p<0.05$ ). 


\section{Discussion}

The previous results suggest that $E$ intestinalis growth is favoured in muddy bare bottom pools in relation with Spartina maritima covered pools, sandy pools and the low-depth channel. Results also suggest that these differences be partially explained by different nutrient dynamics within the tidal pools related with nutrient effluxes from the sediment to the water column.

In the case of $\mathrm{NH}_{4}-\mathrm{N}$, the variation of concentration in the muddy bare bottom pool was in agreement with the result of Lillebø et al. (2002a), which found out that in this type of intertidal pools, ammonia efflux oscurs both during night and day, In fact. the observed increase of $\mathrm{NH}_{4}-\mathrm{N}$ concentration in the muddy bare bottom pool throughout the experiment suggests that ammonia efflux took place during the day and that, the efflux rate was higher than the rate of $\mathrm{NH}_{4}-\mathrm{N}$ uptake by macroalgae. The low $\mathrm{NH}_{4}-\mathrm{N}$ concentrations in the sandy pool and the decrease throughout the experimental period are explained by the low organic matter content of the sediments ( $0.95 \%$. Flindt et al. 2002, Lillebø et al. 2002a) and by macroalgal uptake. Additionally, Flindt et al. (2002) found that, in the sandy pools, the particulate organic nitrogen ( $P O N$ ) is less degradable than in the other experimental pools, which results in low porewater nutrient concentrations and low efflux rates from the sediment to the water column.

The variation of $\mathrm{NH}_{4}-\mathrm{N}$ in the Spartina maritima covered pool is also in agreement with the result of Lillebø et al. (2002a), who measured a lower $\mathrm{NH}_{4}-\mathrm{N}$ efflux, during the day, in S. maritima covered pools compared to the muddy bare bottom pools. Apparently, in the presence of light due to plant photosynthesis and $\mathrm{O}_{2}$ translocation, Spartina maritima roots contribute to oxidise the surrounding sediment, which promotes lower ammonia efflux rates (Lillebo et al. 2002a). The decrease in $\mathrm{NH}_{4}-\mathrm{N}$ concentration that was observed from 11 to $12 \mathrm{a} . \mathrm{m}$. in the Spartina maritima covered pool must reflect both the uptake by macroalgae and the lower $\mathrm{NH}_{4}-\mathrm{N}$ efflux.

Thus, it seems to exist a parallelism between $\mathrm{NH}_{4}-\mathrm{N}$ efflux rates and $E$. intestinalis growth. which in summer are higher in muddy bare bottom pools, followed by Spartina moritimo covered pools and finally by sandy bare bottom pools. This result is corroborated by the values for potential macroalgal growth ( $\mathrm{g}$ WW. $\mathrm{m}^{-2} . \mathrm{d}$ ') estimated for the different pools, based on daily (including night and day values) $\mathrm{N}$-availabilty calculated by Lillebe et al. (2002a) (Table 2). Assuming a C:N ratio of 10 and that carbon constitutes $40 \%$ of macroalgal dry weight, which corresponds to experimentally obtained values for Chlorophyta (e.g. Viaroli et al. 1993, Thompson and Valiela 1999), in summer, the $\mathrm{N}$-availability in the mud pools may potentially contribute

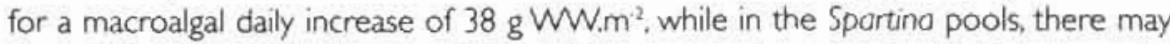

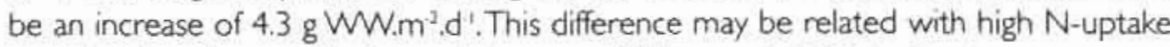
rates by the plant at this time of the year (Lillebø et al. 2002a). On the contrary, in autumn, the potential for macroalgae growth based on $\mathrm{N}$-availability is very similar in the Spartina and in muddy pools and even slightly higher in the Spartina pool (Table 2). This may be related with the higher organic matter content of these pools (see above, 
Table 2. Potential macroalgal weight increase (wet weight) in different intertidal pools in summer and autumn estimated from $\mathrm{N}$-availabity calculated by Lillebø et al. $200 \mathrm{l}$ a and considering a $\mathrm{C}: \mathrm{N}=10$ and that $\mathrm{C}$ constitutes $40 \%$ of macroaigae dry weight. $\mathrm{Nenter-}$ $\mathrm{N}$ concentration in $\mathrm{mg} \mathrm{N} \cdot \mathrm{m}^{2} . \mathrm{d}, \mathrm{N}$ m- $\mathrm{N}$ internal requirement for maximum growth (7.4 $\mathrm{mg} N(\mathrm{gDW})$ '.d'. Pedersen and Borum 1996). Pmemer.P concentration in $\mu \mathrm{mol} . \mathrm{m}^{2}$. $\mathrm{d}^{\prime}$ calculated by Lillebø et al. 200 la,b. Vmax-rate of uptake at phosphate saturation ( 96 umol P (gDW) '. $d^{\prime}$, in Poole and Raven. 1997)

\begin{tabular}{|c|c|c|c|c|c|}
\hline \multirow{2}{*}{$\begin{array}{c}\text { Season } \\
\begin{array}{c}\text { Type of } \\
\text { intertidal pool }\end{array}\end{array}$} & \multicolumn{2}{|c|}{ Summer } & \multicolumn{3}{|c|}{ Autumn } \\
\hline & Spartina pool & Mud pool & Spartina pool & Mud pool & Sand pool \\
\hline $\begin{array}{c}\text { Potential } \\
\text { macroalgal } \\
\text { growth } \\
\text { (gWW.m². }\end{array}$ & 4.3 & 38 & 65 & 59 & 11 \\
\hline$N_{\text {montutap }} / N_{\text {res }}$ & 2.7 & 24 & 41 & 37 & 7 \\
\hline$P_{\text {mathber }} / N_{\text {max }}$ & 10 & 22 & 13 & 6 & 18 \\
\hline
\end{tabular}

Flindt et al. 2002) and with the possible lower uptake rates by the plant at this time of the year (Lillebø et al. 2002a).

Assuming a $\mathrm{N}$-internal requirement of $7.4 \mathrm{mg} \mathrm{N}(\mathrm{g} \mathrm{DW})^{-1} \mathrm{~d}^{\prime}$ for the maximum growth of opportunistic macroalgae (Ulva sp., Pedersen and Borum 1996), the Navailability per square meter in the Mondego intertidal pools range between $3-40$ times this value (Table 2), which indicates the high potential for macroaigae growth within these pools.

According to Lillebø et al. (2002a), in summer, phosphate efflux is higher in muddy bare bottom pools followed by Spartina manitima covered pools and the sandy bare bottom pools, however such pattern is not clear in the present results. This difference could have been partially determined by temperature. In July 1997, Lillebø et al. (2002a) registered a maximum temperature of $32^{\circ} \mathrm{C}$. while in the present study, the maximum temperature was $25^{\circ} \mathrm{C}$. Actually, phosphate efflux is promoted by higher temperatures and by increased redox-state of the sediment (Valiela 1995. Lillebo et al. 2002a). This may explain the difference between the present results and those of Lillebø et al. (2002a).

282 Nevertheless, if we consider the initial concentration (1.35 $\left.\mu \mathrm{mol} \mathrm{PO}_{4}-\mathrm{PI}^{\prime}{ }^{\prime}\right)$ at $9 \mathrm{a} . \mathrm{m}$. in the

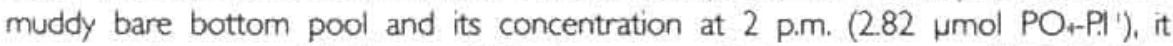
corresponds to a two-fold increase. This also agrees with the occurrence of $\mathrm{PO}_{4}-\mathrm{P}$ efflux during the day in this type of pools as measured by Lillebø et al. (2002a).

The increase in $\mathrm{PO}+\mathrm{P}$ concentration verified in Spartina maritima pool from 9 to $10 \mathrm{am}$. could have resulted from the occurrence of strong anoxic conditions during the night associated with the presence of the rooted-macrophyte. In this situation. reduced conditions may persist until the next morning (until the point when $\mathrm{O}_{2}$ consumption is balanced by $\mathrm{O}_{2}$ production). Under anoxic conditions, sediments may 
turn from sinks to sources of phosphorus (Sfriso et al. 1988. Perttilä et al. 1995, Flindt et al. 2002, Lillebø et al. 2002a,b).

Although in summer, $\mathrm{PO}_{4} \mathrm{P}$ effluxes are higher in the muddy pools (Lillebo et al. 2002a,b). Spartina maritima covered pools present the highest initial and average POA-P concentrations. This may reflect the fastest mineralisation rates promoted by the highest organic matter content of the sediments in the Spartina covered pools (Flindt et al. 2002).

The ratio of total (day and night) PO4-P availability in each type of intertidal pools (Lillebo et al, 2002a) by the maximum rate of phosphate uptake $\left(V_{\max }=96 \mu\right.$ mol $P$ (gDW) ${ }^{-1} d^{-1}$ in Poole and Raven 1997) suggests PO4-P sufficiency in all pools (Table 2). In autumn, there is a slight increase of this ratio in the Spartina pool compared to summer, which again such as in the case of nitrogen may reflect seasonal plant growth variations. The significant decrease verified in the mud pool in autumn compared with the summer value may be related with temperature variation. The highest value of $P_{\text {mara }} N_{\text {max }}$ in autumn was measured in the sand pool, which is apparently unexplained.

The low NO-N concentrations verified in the water of tidal pools are in accordance with other values measured during summer in the Mondego estuary (Pardal 1998, Martins 2000, Martins et al. 2001, Flindt et al. 2002). However. the observed decrease in $\mathrm{NO}_{3}-\mathrm{N}$ concentrations especially in the muddy bare bottom and in the Spartina maritima covered pool is not completely explained by macroalgal uptake. In fact, most marine algae seem to preferably take up $\mathrm{NH}_{4}-\mathrm{N}$ over $\mathrm{NO}_{3}-\mathrm{N}$ (Valiela 1995), particularly if $\mathrm{NH}_{4-} \mathrm{N}$ concentration exceeds that of $\mathrm{NO}=\mathrm{N}$ (Riccardi and Solidoro 1996) as was the case. It is possible that, denitrification processes be related with $\mathrm{NO}_{3}-\mathrm{N}$ depletion in tidal pools during summer, particularly in the presence of rooted vegetation (Valiela 1995, Flindt et al. 1999).

Nutrient dynamics in the subtidal channel depends on other factors (e.g. hydrodynamics), which may not be significant to nutrient dynamics in the tidal pools. In the present results, the difference between nutrient dynamics in intertidal pools and the subtidal channel areas was more evidenced by $\mathrm{NO}_{3}-\mathrm{N}$, which was always higher and less variable in the channel compared with the intertidal pools. This is in agreement with previous results (Pardal 1998, Martins 2000, Martins et al. 2001), which suggested that the $\mathrm{NO}_{3}-\mathrm{N}$ enrichment of the system depends mainly on the input from external sources (namely from the Pranto River, see Fig. 1). Several factors related with hydrodynamics (e.g. higher light extinction coefficients) may contribute to a lower macroalgal growth in the channel relatively to the muddy bare bottom pools. However. the suitability of the subtidal channel to macroalgal growth, at this time of the year, is very similar to that of Spartina maritima covered pools and sandy pools. It is also possible that in the Spartina maritima (average plant height $=50 \mathrm{~cm}$ ) pools, macroalgae suffer from light-limitation, especially in early morning and late afternoon, when shading by the rooted plant is higher.

The variation in N:P ratios of the water suggest a strong potential of N-limitation in all places except the muddy bare bottom pool and particularly in the sandy pool. Nevertheless. $E$. intestinalis grew in all places. which may be related with macroalgal nutrient storing capacity (Björnsäter and Wheeler 1990, Fong et al. 1998). Although macroalgae-storing capacity is lower than that of seagrasses, macroalgal growth is 
considered to depend on internal nutrient concentrations (Björnsäter and Wheeler 1990, Bendoricchio et al. 1994, Solidoro et al. 1997), while their uptake rates depend on the difference between internal and external nutrient concentrations. Nevertheless, the present results suggest that the differences in $E$ intestinalis growth between places might have been related with different $N: P$ ratios in the different experimental places. In fact, the rate of dependency on external conditions is also determined by macroalgal growth rate (Poole and Raven 1997). If macroalgae growth is low, it can rely for a longer period in internal storage than if growth is higher, as was the case. However, the significant $\mathrm{N}$-limitation of the water in the sandy pool, Sportino pool and the channel did not necessarily cause $\mathrm{N}$-limitation of $\mathrm{E}$. intestinalis but it might have contributed to slow down their growth in relation with $E$ intestinalis growth in the muddy pool.

In conclusion, the present results show that different nutrient availability causes distinct growth responses of green macroalgae in different tidal pools. Nevertheless. between muddy bare bottom and muddy vegetated pools, nutrients may not be the only factor contributing for the different growth of green macroalgae. In fact, although the presence of rooted vegetation affects nutrient dynamics within intertidal pools. light-limitation of macroalgal growth due to shading by high rooted-macrophytes is likely to occur.

Furthermore, this work highlights the importance of nutrient effluxes from the sediment to the growth of opportunistic macroalgae. Although seasonal differences take place, the nutrients provided by the sediment-water effluxes provide enough nutrients to allow maximum macroalgal growth, suggesting that in terms of nutrients, the occurrence of macroalgal blooms in the south of the estuary may be independent from external input. On the other hand, the effective growth of macroalgae will depend on the variation of other factors (e.g. light conditions, salinity, current speeds, N:P ratio see Martins et al. 2001 ) that will control altogether the productivity of this primary producer.

At the system level, these results may at a certain extent explain the higher abundance of new macroalgal individuals in muddy areas during late winter/early spring. At this time of the year, when external conditions are still unstable (e.g. high tidal currents due to high input of freshwater, high, light extinction coefficients, low salinity). the places with a higher nutrient availability may be comparably more suitable to macroalgal growth.

\section{Acknowledgements}

This work was supported by the Portuguese Foundation for Science through a PhD grant attributed to I. Martins (PRAXIS BD/3744/94) and by the EU project "WET - Wetland Ecology and Technology (FMRX - CT96-005I. Inside this frame IMAR and Freshwater Biological Laboratory, University of Copenhagen, Denmark, made the joint scientific study in the Mondego Estuary. The study was also supported by the European Scientific MAST 3 program (the F-ECTS project) inside the ELOISE frame. 


\section{References}

Bendoricchio, G, Coffaro, G., and De Marchi, C. 1994. A trophic model for UMva ngida in the Lagoon of Venice Ecol. Model. 75/76: 485-496.

Biörnsäter, BR and Wheeler. PA. 1990. Effect of nitrogen and phosphorus supply on growth and tissue composition of Ulva fenestrata and Enteromorpha intestinalis (Ulvales, Chlorophyta). I. Phycol. 26:603.611

Brown, D. and Rothery. P. 1994. Models in Biology. Wiley, England

Falcāo. M. and Vale, C. 1990. Study of the Ria formosa ecosystemt benthic nutrient remineralization and tidal variability of nutrients in water. Hydrobiologia 207: 137-146.

Flindt, M.R. Pardal, M.A., Lilebø, AL, Martins, L. and Marques. J.C. 1999. Nutrient cyding and plant dynamics in estuaries: A bnef revew. Acta Oecol, 20: 237-248.

Flindt.M.R. Pardal. M.A., Llliebo. A.L., Martins, L and Oliveira I.M. (2002). Nutrient dynamics in the intertidal pools of the Mondego Estuary. I - Nutrients sources, sediment profiles, mineralisation and adsorption dynamics Aquatic Ecology of the Mondego River Basin. Global importance of local experience. (This volume)

Fong, P. Boyer. KE. and Zedler. J.B. 1998. Developing an indicator of nutrient ennchment in coastal estuanes and lagoons using tissue nitrogen content of the opportunistic alga. Enteromorpha intestinalis ( $L$ Link) . Exp. Mar. Biol. Ecol., 231: 63.79.

Hernández, L, Peralta, G, Pèrez-Lloréns, JL. Vergara, If. and Niell, FX 1997. Buomass and dymamics of growth of Ulva species in Palmones River Estuary. I Phycol 33: 764-772.

Lillebe, AL, Flindt, M.R., Pardal, M.A and Marques, J.C. 1999. The effect of macrofauna, meiofauna and microfauna on the degradation of Spartina marituma detritus from a salt marsh area. Acta Oecol. 20: 249-258.

Lillebø. AL, Flindt. MR. Pardal, M.A. Martins, L. Neta. J.M, and Marques, J.C. (2002a). Nutnent dynamics in the intertidal pooks of the Mondego Estuary II - Seasonal Efflux of PO.P and NHo-N in bare bottom and vegetated pools. Aquatic Ecology of the Mondego River Basin, Global importance of local expenence. (This volume)

Lillebø, A.L, Flindt. M.R, Parda, M.A., Martins, L. Neto, J.M. and Marques, J.C. (2002b) Nutrient dynamics in the intertidal pools of the Mondego Estuary. N - Possible contribution to dissolved inorgaruc phosphorus loading.Aquatic Ecology of the Mondego River Basin. Global importance of local experience. (This volume)

Martins, L.C. 2000. Green macroalgae and seagrasses in a shallow eutrophic estuary. the Mondego Estuary. Dynamics controlling factors and possible evolutionary scenarios. Ph.D Thesis. FCT.University of Coimbra.

Martins. L., Pardal, MA, Liliebo. A.L. Findt. MR and Marques, I.C. 2001. Hydrodynamics as a major factor controlling the occurrence of green macroalgae blooms in a eutrophic estuary. A case study on the influence of precipitation and mer management. Estuar. Coast. Shelf $5 \mathrm{cL}$. 52:165-177

Morand. P. and Briand. X 1996. Excessive growth of macroalgae: a symptom of emvironmental disturtance. Bot. Mar. 39: 491.516

Pardal, MA 1998. Impacto da eutrofizaçào nas comunidades macrobentónicas do braço sul do estuário do Mondego, PhD Thesis, FCT-Unmersity of Combra.

Pardal. M.A. Marques. J.C. Metelo. L. Lillebø. A. and Flindt. MR 2000, Impact of eutrophication on the life cycle. population dynamics and production of Amphithoe valida (Amphipoda) along an estuarine spatial gradient (Mondego estuary. Portugal). Mar. Ecol. Prog, Ser. 196: 207.219.

Pedersen, M.F, and Borum, 1996. Nutnent control of adgal growth in estuarine waters Nutrient limitation and the importance of nitrogen requirements and nitrogen storage among phytoplancton and species of macroalgae. Mar. Ecol Prog Ser. 142:261.272

Pertulä, M., Niemistö, L. and Makelä, K.995. Distrnbution, development and total amounts of nutnents in the Gulf of Finland. Estuar Coast. Shelf Sct, 41:345-360.

Pith. L., Svenson, A. Mokenes, P.O. and Wennhage. H. 1999. Distribution of green algal mats throughout shallow soft bottoms of the Swedish Skagerrak archipelago in relation to nutrient sourtes and wave exposure. . Sea Res 41: 281-294

Poole. LJ, and Raven. JA 1997. The brology of Enteromorpho. Prog. Phyc. Res, 12 (F.E. Round/DJ. Chapman, eds). Biopress Ltd, I23pp.

Ruccardi, N. and Solidoro, C. 1996. The influence of environmental variables on Ulva rigida C. Ag. Growth and production. Bot Mar. 39; 27-32

Sfriso. A. Marcomini. A. Pavoni, B. and Oria. A.A 1988. Macroalgal production and nutrient recycling in the Lagoon of Venice. Ingeg. Sanit: 255-266. 
Sfriso, A. 1995, Temporal and spatial responses of growth of Ulva rigida C. Ag. To environmental and tissue concentrations of nutrients in the Lagoon of Venice. Bot Mar. 38. 557-573

Solidora. C. Pecenik, G. Pastres, R. Franco, D. and Dejak, C. 1997. Modelling macroaigae (Ulvo rigida) in the Venice Lagoon: model structure identification and first parameters estimation. Ecol. Model. 94. 191-206.

Sokal, RR and Rohif, F1. 1995. Biometry, 3rd Edition, Freeman Press, New York, 887 pp.

Thompson. S.M. and Valiela, L. 1999. Effect of nitrogen loading on enzyme activity of macroalgae in estuaries in Waquort Bay. Bot Mar. 42: 1-11.

Valiela. L, 1995. Marine Ecological Processes, 2nd Edition, Springer. pp. 686.

Viaroli, P. Naldi, M. Christan, R. and Fumagalii L. 1993. The role of macroalgae and detritus in the nutrient cycles in a shallow-water dystrophic lagoon. Verh. Intemat Verein. Limnol. 25: 1048-1051.

$\mathrm{Zar}, \mathrm{H}$. 1999, Brostatistical Analysis, 4nd Edivon, Prentice-Hall international, inc. New Jersey, $716 \mathrm{pp}$. 

Série

Investigação

$\bullet$

Coimbra

Imprensa da Universidade

2002 